УДК 347.9

DOI https://doi.org/10.32849/2663-5313/2021.6.36

\title{
Любов Логуш,
}

канд. юрид. наук, дочент,

доцент кафедри приватного права

Національного університету «Києво-Могилянська академія»

\section{МІЖНАРОДНА ПРАКТИКА ЗАСТОСУВАННЯ МЕДІАЦІЇ В ДІЯЛЬНОСТІ ЮРИДИЧНИХ КЛІНІК В УКРАЇНІ}

У статті висвітлено особливості інституту альтернативного вирішення правових спорів (ABC) як процесу, спрямованого на добровільне врегулювання відносин між сторонами, з акцентом на медіаиії як одній із найпоширеніших та найпопулярніших його форм.

Процедури альтернативного вирішення правових спорів (ABC) дозволяють сторонам значною мірою контролювати процес безпосереднього врегулювання спору, впливати на його результат, є гнучкими і можуть бути пристосовані до потреб сторін.

Автором проаналізовано переваги альтернативного вирішення правових спорів (ABC), які полягають у збереженні часу та заощадженні коштів сторін спору, у швидкому врегулюванні спору порівняно із судовою процедурою, у запобіганні псуванню ділових стосунків сторін натепер та в майбутньому. Медіачія і консиліачія є процедурами, до яких залучена третя сторона, котра допомагає сторонам врегулювати спір радше через досягнення компромісу, ніж прийняття рішення. Третя сторона намагається лише знайти компромісне вирішення спору, яке задовольнить потреби та інтереси всіх сторін.

У статті проаналізовано різні форми альтернативного вирішення правових спорів (ABC), зокрема: переговори, консиліацію, медіащію як одну з найпоширеніших і найпопулярніших його форм з акцентом на впровадженні медіачї в юридичній клініиі. Автор резюмує, що медіація в юридичній клініиі дає можливість студентам зробити посередницьку діяльність частиною свого професійного життя та забезпечує хороший професійний старт для молодого правника з точки зору як практичних навичок, так і етики.

Аналізуючи міжнародну практику застосування медіачї̈ у діяльності юридичних клінік в Україн, автор зазначає галузі, в яких застосування міжнародної медіації є найпоширенішим, зокрема: між- і внутрішньокорпоративні суперечки; спори у банківській і страховій сфері; супровід проектів, реалізачія яких зачіпає інтереси багатьох сторін; конфлікти на роботі; сімейні суперечки; спори, пов'язані з авторським правом та інтелектуальною власністю; медіація в освіті; міжкультурні конфлікти і багато іншого.

Автор акиентує увагу на досвіді юридичної клініки (иентру) в Університеті Лойола в Чикаго, Іллінойс, США (Loyola University Law Center, Chicago, Illinois, USA), яку автор мала можливість відвідати і досвід якої варто запозичити правничим клінікам в Украйні.

Автор пропонує запровадити американську модель експериментальної програми з медіачї̈ в юридичних клініках університетів в Україні.

Ключові слова: консиліація; медіація; арбітрування; pro bono; американська модель експериментальної програми з медіації.

Постановка проблеми. Залучення до практичної діяльності юридичних клінік в Україні результатів наукових досліджень у сучасних умовах зумовило необхідність впровадження технологій альтернативного врегулювання спорів у юридичній клініці, що є надзвичайно актуальним та важливим, адже саме застосовуючи медіацію на практиці, студент отримує навички, які неможливо отримати під час звичайного консультування клієнта. Застосування медіації сприяє формуванню у студентів практич- них навичок орієнтування у нормативноправовій базі, презентації не тільки себе, але й клієнта та його інтересів, вміння глибоко оцінити правову ситуацію та виокремити проблему, яка є причиною конфлікту між сторонами.

Стан дослідження. Питання альтернативного вирішення правових спорів із застосуванням процедури медіації у своїх працях досліджували Н. Крестовська, Л, Романадзе, Форест С. Мостен. Водночас питання застосування медіації в діяльності юридичних клі- 
нік університетів в Україні досліджені наразі недостатньо.

Завданням цієї статті $€$ аналіз питання допустимості використання міжнародного досвіду з медіації для створення української експериментальної програми з медіації, яка б започаткувала введення практичного курсу з медіації в освіті.

Виклад основного матеріалу. У теоpiї і практиці зарубіжних країн позасудове вирішення спорів має ще й іншу назву Alternative Dispute Resolution (ADR) - альтернативне вирішення правових спорів, що підкреслює особливості цього інституту, який вважається альтернативним судовому провадженню [1].

Характерною ознакою альтернативного вирішення спорів є його спрямування на добровільне врегулювання відносин між сторонами. Регулюючий вплив альтернативного вирішення спорів на сторони спору досягається тим, що вони йдуть на це добровільно, усвідомлюючи переваги такого вибору та бажаючи дійти згоди щодо спірних відносин.

Процедури альтернативного вирішення правових спорів дозволяють сторонам значною мірою контролювати процес безпосереднього врегулювання спору, впливати на його результат та $є$ дуже гнучкими, можуть бути пристосовані до потреб сторін. Альтернативне вирішення спорів $€$ конфіденційним процесом. Рішення по спору не $€$ обов'язковим, якщо лише сторони в письмовій формі не погодили протилежне. В останньому випадку рішення стає обов'язковим згідно із законом, що застосовується до контракту сторін.

Перевагами альтернативного вирішення спорів $\mathrm{\epsilon}$

- збереження часу та заощадження коштів;

- швидше врегулювання, ніж у судовому порядку;

- запобігає псуванню ділових стосунків натепер та в майбутньому;

- зберігає та підвищує ділову репутацію сторін;

- процес позасудового вирішення спорів $€$ простим та доступним, допомагає уникнути надмірно завантаженого процесу дослідження доказів (включаючи й опитування свідків), що зазвичай характерне для судового провадження, забезпечує стислість в наданні інформації сторонами та мінімум необхідних документів;

- забезпечує конфіденційність, процес $є$ приватним, не ведеться записів чи протоколів;
- має необов'язковий характер, оскільки сторони можуть припинити процедуру в будь-який час; рішення, якого досягнуть сторони, є необов'язковим, повне покладання на бажання та волю сторін примиритися;

- задіяні представники сторін мають достатні повноваження, тому процес позасудового вирішення спорів та його результат перебувають під контролем сторін;

- високий рівень задоволення результатом у разі досягнення згоди, оскільки сторони самі беруть участь у виробленні результативного та вигідного рішення;

- після позасудового вирішення спорів можна звертатися до судового захисту своїх прав [2].

Альтернативне вирішення спорів включає переговори; консиліацію; медіацію та арбітрування.

Переговори (negotiation). Проведення переговорів між учасниками спору, як одного 3 дієвих механізмів досудового вирішення спорів, регулюється не нормативно-правовими актами, а правилами ділової етики, тобто його ефективність залежить переважно від «переговорних» здібностей сторін та їхніх психологічних навичок. Хоча цей механізм $€$ найпоширенішим серед альтернативних механізмів вирішення спорів в Україні, він не завжди дає бажаний результат, особливо коли сторони не хочуть виносити певне питання на розгляд суду.

У переговорному процесі традиційно виділяють три стадії його реалізації. Перша стадія бере свій початок з моменту ініціації проведення переговорів, де відбувається підготовка до їх проведення, та характеризується збором юридичного анамнезу, проведенням аналізу проблем та визначенням можливих варіантів їх вирішення. Важливим на чій стадії є розробка загального підходу до переговорів, а також прогнозування й оцінка можливих запропонованих опонентом варіантів і пропозицій розв'язання спору.

Друга стадія - безпосереднє ведення переговорів, результати якого прямо залежать від першої стадії. Так, на цій стадії опонентам необхідно знайти «спільну мову» та подати свої пропозиції стосовно оптимального для них вирішення суперечностей, після чого відбувається обговорення, обгрунтування та визначення меж можливої домовленості. Фінальним етапом цієї стадії є узгодження запропонованих пропозицій.

Третя стадія - безпосередній аналіз результатів переговорів і виконання досягнутих домовленостей [2].

Консиліація (Conciliation). Одним із перших міжнародно-правових документів, у якому міститься положення про врегулю- 
вання спорів через досягнення компромісу (примирювальна процедура), є Вашингтонська конвенція 1965 року. Зазначена конвенція в Главі Ш передбачає примирювальні процедури, у яких бере участь третя сторона. Однією з них є медіація, іншою консиліація [3].

Сутність консиліації полягає в тому, що особливим чином формується комісія примирення, яка визначає предмет спору між сторонами та прагне досягнути угоди між ними на взаємовигідних умовах. Процедура консиліації є конфіденційною, а запропонований варіант рішення - необов'язковим для сторін.

В Україні консиліація є процедурою маловідомою, більшість відомостей про дану процедуру міститься в іноземних джерелах.

У межах зазначених форм можна виділити одну з найпоширеніших та найпопулярніших форм - медіацію.

Медіація (Mediation) - це насамперед добровільний та незалежний процес: сторони можуть ініціювати іï в будь-який час існування спору між ними та незалежно від того, чи розпочато судовий процес провадження в даній справі, чи ні. Медіація являє собою приватний процес добровільного врегулювання спору сторонами за участю третьої незалежної та неупередженої особи (медіатора), яка призначається за згодою сторін та допомагає знайти компромісне вирішення спору, яке задовольнить потреби та інтереси всіх сторін. Зокрема, медіація є безболісним для репутації та більш заощадливим способом вирішення конфліктів у фінансовому секторі. Ї̈̈ вже давно практикують у США та багатьох країнах Європи та Азії.

Принципи медіації визначено у ст. 3 проєкту Закону України «Про медіацію»: добровільна участь, конфіденційність, незалежність та нейтральність медіатора, неупередженість медіатора, самовизначення та рівність прав сторін медіації [4].

Медіатор має на меті досягнення чітких домовленостей між учасниками спору, зокрема про те, як сторони будуть вирішувати конкретні питання. Вiн не бере до уваги виявлення будь-яких почуттів під час процедури медіації. Медіатор зосереджений на перспективі взаємин сторін спору, а не на аналізі минулих відносин сторін. Він контролює процес і не впливає на учасників процесу медіації або результат, водночас сам організовує проведення процедури. Медіатор допомагає сторонам конфлікту визначити реальні інтереси, коло спірних правовідносин і самостійно виробити угоду щодо спору, до того ж сторони конфлікту повністю контролюють процес прийняття рішення з урегулювання спору і умови розв'язання спірної ситуації. Медіатор полегшує процес спілкування між сторонами конфлікту, розуміючи позиції та інтереси кожної з них, фокусує сторони на їхніх інтересах і допомагає у пошуку продуктивного розв'язання проблеми, надаючи їм можливість виробити угоду самостійно. Медіаційна процедура проходить у кілька етапів, які об'єднані однією метою вирішення спору альтернативними судовому провадженню методами, що дозволять сторонам дійти згоди на взаємовигідних засадах. Для успішного проведення медіації потрібно, щоб перехід до наступного етапу відбувався після того, як будуть досягнуті усі цілі на попередньому. Виділяють такі етапи процесу здійснення медіації: підготовка до посередництва; вступ у процедуру медіації; обговорення проблеми, пошук та розробка варіантів вирішення спору; вирішення спору, укладення угоди та підбиття підсумків [5, с. 228-290].

Натепер в Україні не існує спеціального формалізованого законодавства, що регулює здійснення медіації. Проєкт Закону України «Про медіацію» № 3504 був зареєстрований у Парламенті України 19.05.2020 року. Але водночас не існує і жодної формальної заборони з боку держави сторонам здійснювати медіацію. Відповідно до ч. 4 ст. 55 Конституції України, держава гарантує можливість кожному будь-якими не забороненими законом способами захищати свої права. Отже, можемо стверджувати, що в Україні $€$ конституційне підгрунтя здійснення медіації. Указ Президента України від 20 травня 2015 року № 276/2015 «Про Стратегію реформування судоустрою, судочинства та суміжних правових інститутів» [6] в п. 5.4 передбачає підвищення ефективності правосуддя та оптимізацію повноважень судів різних юрисдикцій, а саме: розширення способів альтернативного (позасудового) врегулювання спорів, зокрема, шляхом практичного впровадження інституту медіацї i посередничтва, розширення переліку категорій справ, які можуть вирішуватися третейськими суддями або розглядатися судами у спрощеному провадженні; запровадження ефективних процесуальних механізмів для попередження розгляду справ за відсутності спору між сторонами; вивчення доцільності введення мирових суддів.

У 2014 р. Україна підписала Угоду про Асоціацію 3 Європейським Союзом [7]. Згідно зі статтею 1 Угоди, Україна і СС мають посилювати співпрацю у сфері правосуддя, свободи та безпеки з метою забезпечення верховенства права та поваги до прав людини і основоположних свобод. Країни Свропей- 
ського Союзу погодилися, що забезпечення верховенства права та кращого доступу до правосуддя повинно включати доступ як до судових, так і до позасудових методів урегулювання спорів. Європейська Рада на своєму засіданні в Тампере 15.10 .99 р. закликала держави-члени до запровадження альтернативних позасудових процедур, серед яких медіація є основною, а також низку рекомендацій та керівних принципів.

Законодавче закріплення медіації забезпечить приведення чинного в Україні законодавства щодо альтернативного вирішення спорів у відповідність до стандартів ЕС та імплементує норми статті 5 Директив 2008/52/ЕС Свропейського Парламенту та Ради Свропи у національне законодавство України, що створить умови для роботи медіаторів в єдиному європейському правовому просторі та сприятиме розвитку інституту медіації в Україні [8].

Крім Директиви 2008/52/ЕС, існує низка міжнародно-правових актів та актів рекомендаційного характеру, норми яких доцільно імплементувати Законом України «Про медіацію». Зокрема, це Модельний Закон ЮНСІТРАЛ про міжнародну примирну процедуру 2002 р., який був взятий за основу для національного законодавства щодо медіації 26 країнами світу, та «Принципи для організацій, які забезпечують проведення медіації», які були створені в 2002 р. світовими лідерами у сфері медіації і відтворюють найкращу світову практику в цій галузі [9].

Імплементація європейських та міжнародних стандартів в українське законодавство сприятиме розвитку громадянського суспільства та формуванню культури мирного цивілізованого вирішення конфліктів на засадах взаємних інтересів та згоди.

Медіачія в юридичній клінічі дає можливість студентам зробити посередницьку діяльність частиною свого професійного життя та забезпечує хороший професійний старт для молодого правника з точки зору як практичних навичок, так і етики. Медіація допомагає студентам побачити переваги й недоліки посередництва та інших альтернативних методів вирішення спорів. Таким чином, студенти отримують навички відповідального консультування клієнтів за власним вибором засобу правового захисту порушеного права клієнта; медіація також допомагає студентам зрозуміти, як почуття, фонові значення й особистий стиль впливають на продуктивність у професії.

У рамках юридичної клініки студентиюристи проходять підготовку як посередники, які діють як нейтральні треті сторони під час вирішення конфлікту між клієнтами.
Медіація дозволяє сторонам у суперечці контролювати результати їхніх конфліктів, тобто дозволяє конфліктним сторонам самим вирішити конфлікт.

Медіатор, який здійснюватиме процедуру медіації, повинен володіти вмінням усувати конфлікти і мати знання не лише у сфері права, а й у таких сферах, як психологія, соціологія, педагогіка, які є необхідними для іiї проведення. Саме тому медіація в юридичній клініці дозволяє розвинути у студентів-юристів активні навички за фахом.

Юридична клініка, яка впроваджує медіаиію, виконує три головні функціи:

- формування у студентів навичок посередника, що допомагає їм краще інтегрува тися у суть правової ситуаиї та проблеми, що спричинила конфлікт, а також навичок швидкого вирішення проблеми, орієнтуючись у практичі застосування закону;

- поліпшення здатності студентів ефективно представляти інтереси клієнтів, допомагаючи їм вчитися, в контексті посередництва, правильного вислуховування, анкетування, переконання, навичок ведення переговорів і вирішення конфліктів, що має основоположне значення для юридичної практики;

- надання допомоги студентам в оціниі переваг і недоліків посередництва та інших процедур вирішення спорів для того, щоб вони могли консультувати клієнтів у майбутньому.

Сьогодні впровадження технологій альтернативного врегулювання спорів у юридичній клініці $є$ надзвичайно актуальним та важливим, адже саме застосовуючи медіацію на практиці, студент здобуває навички, які неможливо отримати під час звичайного консультування клієнта. Зокрема, студент має можливість оволодіти хорошими навичками психолога та розуміння правової ситуації з погляду обох сторін, а не лише сторони, інтереси якої він представляє. Застосування медіації також сприяє формуванню у студентів практичних навичок орієнтування у нормативно-правовій базі, презентації не тільки себе, але й клієнта та його інтересів, вміння глибоко оцінити правову ситуацію та виокремити проблему, яка є причиною конфлікту між сторонами.

Міжнародна практика застосування медіачї̈ у діяльності юридичних клінік в Украйні.

Медіація стала розвиватися в другій половині XX сторіччя передусім у країнах англосаксонського права - США, Австралії, Великій Британії, після чого почала поширюватися і в Європі. Перші спроби застосування медіації, як правило, стосувалися вирішення спорів у сфері сімейних стосун- 
ків. Згодом медіація дістала визнання у вирішенні широкого спектра конфліктів і суперечок, починаючи від конфліктів у місцевих громадах і закінчуючи складними багатосторонніми конфліктами у комерційній та публічній сферах.

Галузі, в яких застосування міжнародної медіації $€$ найпоширенішим: ечки;

- між- $і$ внутрішньокорпоративні супер -

- спори у банківській і страховій сфері;

- супровід проектів, реалізачія яких зачіпає інтереси багатьох сторін;

- конфлікти на роботі;

- сімейні суперечки;

- спори, пов'язані з авторським правом та інтелектуальною власністю;

- медіачіл в освіті;

- міжкультурні конфлікти і багато іншого.

Взагалі, процедура медіації є дуже поширеним способом вирішення спорів у всьому світі, не тільки в англосаксонській системі права, а й у країнах романо-германської правової сім'ї. Як приклад розглянемо американську експериментальну програму медіації 3 використанням добровольців-медіаторів, започатковану в США на початку 1970-х рр. у декількох великих містах. Вона виявилися настільки успішною, що сотні інших програм були проведені по всій країні протягом двох наступних десятиліть, і сьогодні практика медіації досить поширена в Сполучених Штатах. Судова практика США орієнтована на те, щоби більшість спорів вирішувалася добровільно до судового засідання, а суддя може перервати суд і порадити сторонам попрацювати з медіатором. Без медіаторів у сфері економіки, політики, бізнесу в цій країні не проходить жоден серйозний переговорний процес, випускаються журнали, що висвітлюють проблеми медіації («Щоквартальний журнал 3 медіації»). Існує Національний інститут дозволу диспутів, який займається розробкою нових методів медіації, діють приватні та державні служби медіації. Великий вплив має Американська арбітражна асоціація (American Arbitration Association), яка затвердила свої Правила арбітражного розгляду та медіації, що успішно використовуються в тому числі у розгляді внутрішніх суперечок [10]. Цікавими для ознайомлення $€$ рекомендації американського адвоката Фореста С. Мостена, який практикує в галузі медіації [11, с. 127-135].

Зокрема, американські адвокати застосовують медіацію як основу своєї юридичної практики. Вони виділяють клієнта як центральну особу під час консультування. Під час інтерв'ювання клієнта адвокати намагаються збирати персональну інформа- цію та факти, необхідні для прийняття остаточного рішення та фактичної підтримки клієнта.

Доречним буде акцентувати увагу на досвіді юридичної клініки (центру) в Університеті Лойола в Чикаго, Іллінойс, США (Loyola University Law Center, Chicago, Illinois, USA), яку автор мала можливість відвідати і досвід якої варто запозичити правничим клінікам в Україні.

Юридична клініка має 30-тирічний міжнародний досвід функціонування. Мета клініки - це навчання студентів і надання правової допомоги бідним людям.

Юридична клініка складається з трьох окремих клінік (підрозділів), які співпрачюють між собою:

- Юридична клініка у справах сімейних, бізнесу

- Юридична клініка у справах ведення

- Юридична клініка у справах оподаткування.

Студентами юридичної клініки є студенти 3-го року навчання, для яких обов'язковими є 54 години навчання у клініці, студент отримує 4 кредити за успішне проходження навчання. Студент користується посібником (Office Manual, 2012, Loyola University Law Center, Chicago, Illinois) [12], у якому викладено політичні і процедурні питання діяльності правничої клініки. Студент клініки має у своєму провадженні 3-4 справи, робота над якими складається 3 таких етапів. Перший етап - це вивчення справи і проведення переговорів з клієнтом, під час яких у разі необхідності виникає пропозиція проведення процедури медіації, у якій повинен бути задіяний практикуючий адвокат з медіації. На проведення першого етапу студентові виділяється п'ять тижнів [12].

Другий етап - презентація студентом справи (grand round) перед викладачемкуратором, клієнтом і студентами клініки. Після успішної презентації справи й у разі досягнення медіаційної угоди відбувається підписання медіаційної угоди. У разі неможливості укладення медіаційної угоди відбувається перехід до третього етапу, на якому здійснюється представництво студентом справи клієнта в суді. Згідно з американським законодавством штату Іллінойс, студенти отримують тимчасову ліцензію на практику в суді у справах pro bono.

Яким чином юридична клініка отримує справи? Безпосередньо від населення і від суддів.

Наприклад, справи в клініці із сімейних справ мають міжнародний характер, зокрема, це справи з Гватемали, Мексики, Польщі, які студенти успішно вирішують. 
Чи можливе запровадження американської моделі експериментальної програми 3 медіації в юридичних клініках університетів в Україні?

Звичайно, можливе. Для цього юридичним клінікам університетів необхідно створити українську експериментальну програму 3 медіації, яка б започаткувала введення практичного курсу з медіації в освіті.

Програма повинна передбачати навчання студентів-консультантів юридичних клінік практиці (навичкам) проведення медіації як українськими фахівцями-медіаторами та правниками-практиками в галузі медіації, так і іноземними фахівцями-медіаторами, в тому числі добровольцями-медіаторами 3 іноземних університетських юридичних клінік.

\section{Висновки}

Отже, слід зазначити, що законодавство щодо впровадження програми 3 медіації в юридичні клініки в Україні, яке б започаткувало введення практичного курсу з медіації в освіті, наразі перебуває у процесі становлення. Імплементація європейських та міжнародних стандартів в українське законодавство сприятиме розвитку громадянського суспільства та формуванню культури мирного цивілізованого вирішення конфліктів на засадах взаємних інтересів та згоди.

\section{Список використаних джерел:}

1. ADR Rules of the ICC, 2001: веб-сайт. URL: www.iccwbo.org (дата звернення: 15.05.2021).

2. ICC Mediation Rules, 2014 and Mediation Guidance Notes, 2013.

3. Конвенція про порядок вирішення інвестиційних спорів між державами та іноземними особами : Конвенція; ООН від 18.05.1965 / Верховна Рада України. URL: https://zakon.rada.gov.ua/ go/995_060 (дата звернення: 20.05.2021).

4. Проєкт закону «Про медіацію». URL: http://w1.c1.rada.gov.ua/pls/zweb2/webproc4_1? pf3511=68877 (дата звернення: 20.05.2021).
5. Медіація у професійній діяльності юриста / за ред. Н. Крестовської, Л, Романадзе. Одеса : «Екологія», 2019. 456 с. URL: http:// newjustice.org.ua/wp-content/uploads/2020/02/ Textbook_on_Mediation_for_Law_Schools.pdf (дата звернення: 20.05.202ㅍ).

6. Про Стратегію реформування судоустрою, судочинства та суміжних правових інститутів на 2015-2020 роки : Указ Президента України; Стратегія від 20.05.2015 № 276/2015 / Верховна Рада України. URL: https://zakon.rada.gov.ua/ go/276/2015 (дата звернення: 19.05.2021).

7. Угода про асоціацію між Україною, з однієї сторони, та Європейським Союзом, Європейським співтовариством з атомної енергії і їхніми державами-членами, 3 іншої сторони : Угода; Україна від 27.06.2014 // База даних «Законодавство Украӥни». URL: https://zakon.rada.gov.ua/ go/984 011 (дата звернення: 19.05.2021).

8. Директива № 2008/52/ЄС Європейського парламенту і Ради про деякі аспекти посередництва (медіації) в цивільних та комерційних справах : Директива; ЄС від 21.05.2008 № 2008/52/ EC / Верховна Рада України. URL: https:// zakon.rada.gov.ua/go/994_a95 (дата звернення: 20.05.2021).

9. Модельний Закон ЮНСІТРАЛ про міжнародну примирну процедуру 2002 р. «Принципи для організацій, які забезпечують проведення медіації», 2002 p, Principles for ADR Provider Organizations. URL: http://www.cpradr.org/ RulesCaseServices/CPRRules/PrinciplesforAD RProviderOrganizations.aspx (дата звернення: 20.05.2021).

10. AAA Arbitration and Mediation Rules, 2014. URL: https://iccwbo.org/content/uploads/ sites $/ 3 / 2020 / 12 /$ icc-2021-arbitration-rules-2014mediation-rules-english-version.pdf (дата звернення: 20.05.2021).

11. Forrest S. Mosten, The Lawyer as Collaborative and Preventive Peacemaker, Ch. 2, Reinventing the Practice of Law, Emerging Models to Enhance Affordable Legal Services, ABA Standing Committee on the Delivery of Legal Services Handbook, 2009.

12. Office Manual, 2012, Loyola University Law Center, Chicago, Illinois.

Lyubov Logush. The international practice of using mediation in the activities of legal clinics in Ukraine

This article highlights the peculiarities of the institute of Alternative Dispute Resolution, as a process, aimed at voluntary regulations between parties and emphasizes on mediation as the most widespread and popular form of $A D R$.

The alternative dispute resolution (ADR) procedures can help control the process of direct dispute resolution, influence the results, are flexible and can be adjusted to the needs of the parties.

Mediation and conciliation are procedures in which a third party appears, yet the role of this third party boils down essentially to facilitation of a compromise, rather than decision-making. Third parties only assist the parties to the dispute in their attempt to reach a compromise.

The author has analyzed the advantages of ADR, that lay in time saving, the faster regulation of a dispute comparable to court procedure, also fund savings, and prevention of deteoration of business relationships in the future. The article analisis the different forms of alternative dispute resolution (ADR): negotiations, conciliation, mediation, as of the most popular and widespread form, with a accent of implementation 
of mediation in law clinic. The author resumes that mediation in law clinic gives an opportunity to students to make intermediary activity part of their proffessional life and gives a good start for a young laweyer from practical point of view and ethical as well.

Analyzing the international practice of mediation in law clinic activities in Ukraine, author underlines the brunches, in which mediation is the most commonly recognized, between - and intracorporate disputes, disputes in bank and insurance areas, conduct of projects, the realization of which affects the interest of multiple sides; conflicts at work; household disputes; disputes connected to copyright intellectual property; mediation in education; intracultural conflicts and many more.

The author accents the experience of law clinic in University of Loyola, Chicago, Illinois, USA, which the author had an opportunity to visit

The author offers to implement the American model of experimental mediation program in the activities of the university law clinics in Ukraine.

Key words: conciliation, mediation, arbitration, pro bono, American model experience program of mediation. 